\title{
THE BOUNDARY RELATIONSHIP OF THE CONCERT SCHIST AND THE OONAH QUARTZITE AND SLATE CORRELATE AT DUNDAS
}

by N.J. Turner

Geological Survey of Tasmania

(with two text figures)

ABSTRACT

TURNER, N.J. 1979 (20 vii): The boundary relationship of the concert schist and the Oonah quartzite and slate correlate at Dundas. Pap. Proc. R. Soc. Tasm, 113: 15-20. ISSN 0080-4703. Geoloyical survey of Tasmania, Department of mines, Hobart, Tasmania, Australia.

The boundary between the metasedimentary Concert Schist (Precambrian) and the adjacent correlate of the relatively unmetamorphosed Oonah Quartzite and slate (also Precambrian) at the western edge of the Concert Schist near its type section on Concert Creek near Dundas, Tasmania, is regarded as marking a sharp transition in degree of deformation and metamorphism. Three cleavages, mineral segregation and quartz recrystallisation were found in the concert schist whereas two cleavages and only minor mineral segregation and quartz recrystallisation were found in the Oonah Formation correlate.

Quartz optic axes fabrics obtained from psammites in the Concert Schist and Oonah Quartzite and slate correlate are similar and show relatively weak preferred orientation. These fabrics and fabrics recorded earlier demonstrate that precambrian strata in Tasmania which are classed as metamorphosed cannot in all cases be distinguished from those that are classed as relatively unmetamorphosed on the basis of quartz optic axes fabrics present in psammites.

\section{INTRODUCTION}

B1issett (1962) named the Concert Schist and defined it as 'that group of metasediments which appears to form the basement of the sedimentary succession in the Dundas district. The type section is on Concert Creek between co-ordinates $350500 y$ E $844900 y \mathrm{~N}$ (= CP 717639 Aust. Metric Grid) and $351700 y$ E $845150 \mathrm{y} \mathrm{N}$ (= CP 728641). He correlated the adjacent rocks with the Oonah Quartzite and Slate of Spry (1958). The Concert Schist was considered to be the older unit because it occurs in what was regarded as a structural high. Because of poor outcrop Blissett could not determine whether the unfaulted parts of the boundary between the units marked an unconformity or a transitional change in degree of metamorphism.

Spry (1962) subdivided the Precambrian rocks of Tasmania into metamorphosed and unmetamorphosed strata. A similar distinction has been employed at a regional scale in subsequent Geological Survey publications, for example, the 1:500,000 Geological Map of Tasmania (1976). However, the term relatively or comparatively unmetamorphosed has been used in preference to unmetamorphosed since there are no strictly unmetamorphosed Precambrian strata in the State. In relatively unmetamorphosed strata the pelitic rocks are generally slate and cleaved siltstone and the amount of quartz recrystallisation in psammites has generally been minor. In metamorphosed strata the pelitic rocks are generally phyllites or schists and there has been variable but, commonly, substantial recrystallisation of quartz in psammites. Although the terminology serves well enough at a regional scale, it breaks down at a local scale because there 
are rocks that are relatively unmetamorphosed within sequences that are classed as metamorphosed. For example, Boulter (1974) described units of relatively unmetamorphosed siltstone and mudstone that occur within a sequence of dominanty phyllite, schist and quartzite near Strathgordon in the Tyennan region.

The metamorphosed terrains of the Tyennan region and the small Forth region are considered (Williams 1976) to have been produced by the Frenchman Orogeny and to be older than the relatively unmetamorphosed terrains. Within the relatively unmetamorphosed Rocky Cape region which includes the Donah Quartzite and Slate there is a belt of metamorphic rocks known as the Arthur Lineament. North west of Dundas near Duck Ck. Blissett (op. cit.) found an apparent transition between a part of this belt known as the Whyte Schist and the Oonah Quartzite and slate. Current interpretation of the boundary relationships of the entire Arthur Lineament (Williams, op. cit.) is that they are transitional. The metamorphosed belt and the widespread deformation in the relatively unmetamorphosed rocks were produced during the Penguin Orogeny.

The work reported in this paper was undertaken in order to establish the character of the boundary between the Concert Schist and the Oonah Quartzite and Slate correlate. Good exposure has been provided in recent years by the construction of a vehicular track along the spur immediately south of Concert Creek.

\section{OONAH QUARTZITE AND SLATE CORRELATE}

The part of this unit which outcrops along the track south of Concert Ck. between the Concert Schist and Maestries Siding comprises mainly grey and green, thinly bedded mudstone and siltstone. Thin beds of medium-grained, light-coloured or green sandstone are present in a few places although none were found in close proximity to where the Concert Schist boundary occurs on the track.

Argillaceous material in the mudstone and siltstone has recrystallised to finegrained muscovite that shows strong alignment of flakes. Very fine-grained, 'dusty', opaque material is commonly intermixed with the muscovite and is probably carbonaceous. Smal1 amounts of granular, opaque material are present in both mudstone and siltstone. The alignment of muscovite flakes is penetrative and defines a slaty cleavage. Commonly a weak crenulation cleavage is also present and there can be minor concentration of carbonaceous material in the limbs of crenulations.

The sparse beds of medium-grained sandstone are poorly sorted. They contain about $20 \%$ matrix consisting of fine-grained muscovite and equidimensional quartz and, in one sample abundant green chlorite. Sand-sized grains consist predominantly of undulose quartz with minor, micaceous quartzite and very-fine-grained, muscovite schist. Zircon and subhedra1, opaque mineral are accessories. Alignment of muscovite flakes in the matrix is penetrative and defines a cleavage equivalent to the slaty cleavage in pelitic rocks. No evidence of crenulation of this cleavage was recognized. The cleavage wraps around the sand grains and beards are developed. In many grains, subgrains are present along margins that abut against beards and the entire margins of most grains are pitted indicating some tectonic mass transfer. Overall, the amount of textural modification appears to be minor. The axial ratios of almost all sand grains are less than $2: 1$ and the percentage of matrix probably is close to the percentage prior to deformation. The sandstone was originally quartzwacke.

In the $0.5 \mathrm{~km}$ interval west of Maestries Siding and east of the Cambrian ultramaric rocks the Oonah Quartzite and Slate correlate differs from the sequence described above. Sandstone is much more abundant and the interbedded pelitic material is mainly dark-grey, lustrous slate. The sandstone is fine- to medium-grained, white-weathering and micaceous. It contains about $20 \%$ matrix which consists of fine-grained muscovite and quartz. Sand grains are predominantly undulose quartz with minor, micaceous 


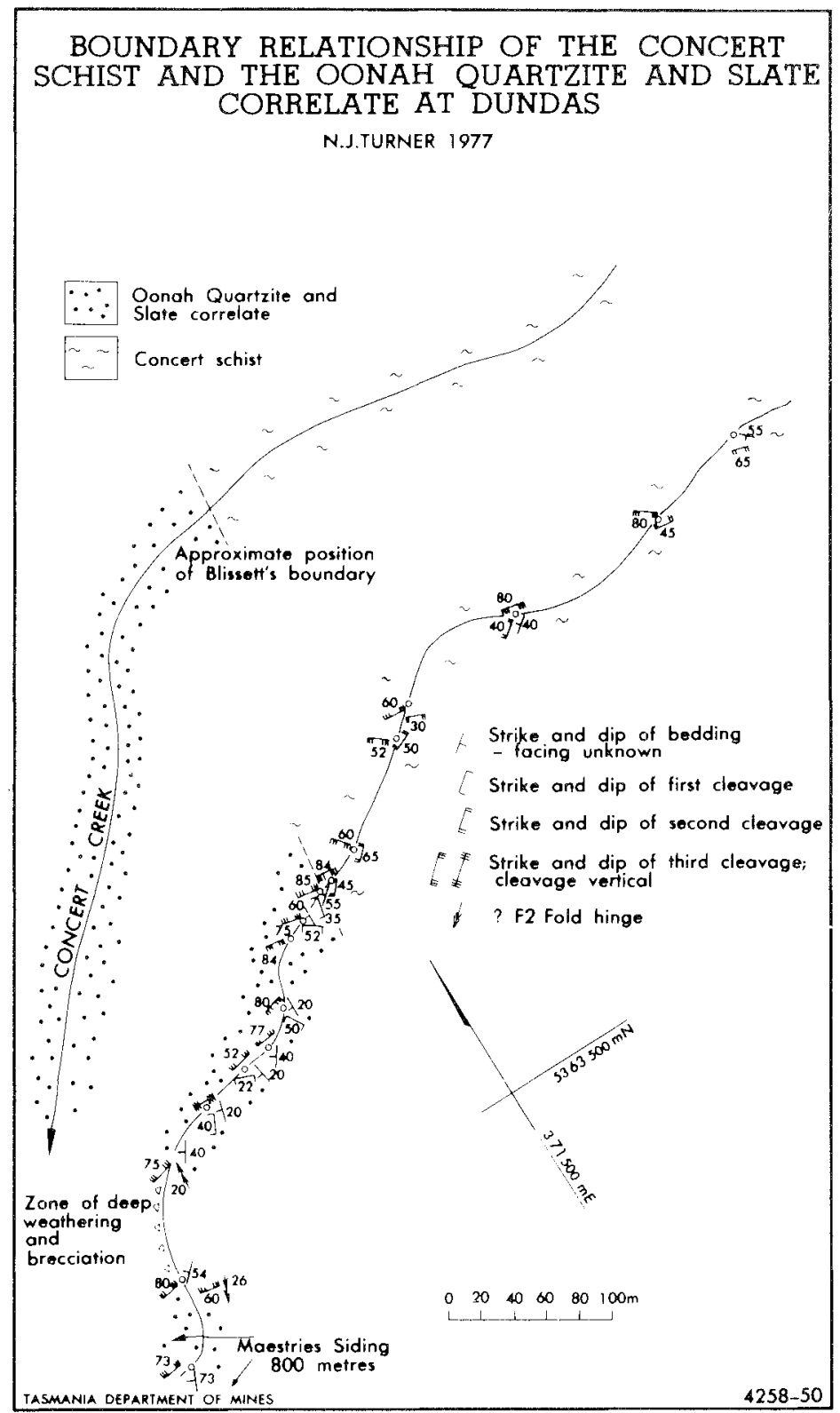

FIG, 1. - Structural measurements near the boundary of the Concert Schist and the Oonah Quartzite and Slate correlate. 
quartzite and muscovite schist. Relatively coarse, detrital grains of muscovite are present. lecause such grains are few in number and because the overall texture of the sandstone shows little modification and is that of a wacke, it is considered that such grains are wholly clastic. Cleavage morphology is similar to that in the sandstone described above, but there is little deflection of cleavage around sand grains, development of beards or of subgrains. Some quartz-rich patches in the matrix have a fine-grained, polygonal character similar to recrystallized material. However, the proportion of matrix and the shape of sand grains which almost all have axial ratios of less than $2: 1$ are thought to reflect the characteristics of the rock prior to deformation.

\section{CONCERT SCHIST}

Material in the portion of the Concert Schist examined is dominantly pelitic and semipelitic. Quartz and muscovite are the principal minerals. Dusty, very-finegrained, probably carbonaceous material and disseminated, euhedral pyrite are abundant in some rocks. Secondary quartz, pyrite and green chlorite occur in small patches and veinlets in many rocks. Three tectonic surfaces are developed the second of which is dominant. In pelitic material the second surface is very closely spaced and difficult to distinguish as a crenulation cleavage in hand specimen, whereas in semipelitic rocks it has thin $(0.5-1 \mathrm{~mm})$ quartz-rich and mica-rich segregation laminae associated with it. The carbonaceous material segregates with the muscovite. Such rocks have a glossy, dark grey, phyllitic character. The first tectonic surface is preserved in some quartz-rich laminae as obliquely oriented fine-grained muscovite flakes and elongate quartz grains. The third surface is a weakly-developed crenulation cleavage which in hand specimen is more commonly evident as a lineation on the second surface than as a cleavage. Segregation of carbonaceous material can be associated with it but no segregation of quartz or muscovite was observed.

A number of beds of white or greenish white, foliated, micaceous quartzite of several metres thickness occur within the pelitic sequence about $1 \mathrm{~km}$ from the boundary on the track south of Concert Ck. They contain $5-10 \%$ muscovite plus accessory subhedra1, opaque mineral and green tourmaline. Two surfaces are defined by preferred orientation of muscovite flakes. An older, poorly preserved, crenulated surface, defined by individual flakes, is transected by the dominant surface which is defined by stringers of muscovite. Two populations of quartz grains are present. Most grains are fine $(0.04 \mathrm{~mm})$, undulose, polygonal quartz, with smooth, gently curved or straight boundaries. In small patches such grains show dimensional orientation parallel to the older muscovite surface. A small proportion $(10-15 \%)$ of grains are coarser $(0.2 \mathrm{~mm})$. These grains are strongly undulose and have low axial ratios. Their margins are irregular and commonly have subgrains developed along then. The subgrains are of similar size to grains in the groundmass and in many instances are intergrown with the groundmass grains such that there is no distinct boundary. This relationship indicates that the groundmass is derived in part from the coarser material by recrystallisation. Because the finer population shows dimensional orientation parallel to the older mica surface the coarser grains must be older than that surface. It is likely that they are modified clastic grains. However, no substantiating evidence, such as preserved sedimentary margins, was established. The third surface of the pelitic rocks was not observed in the quartzite units. The strong tectonic and metamorphic modification of the quartzite within the Concert Schist is in contrast with the sandstone of the Oonah correlate, particularly that west of Maestries Siding. Because of the modification, the type of sediment from which the quartzite was derived cannot be inferred. 
There is good exposure over the interval in which the boundary between the Concert Schist and the Oonah Quartzite and Slate correlate occurs (fig. 1). The following: observations were made -

(1) No substantial change in lithology occurs although the pelitic and semipelitic rocks in the Concert Schist are richer in carbonaceous material than those adjacent to it.

(2) No erosional interface was detected.

(3) No fracturing or displacement indicative of substantial faulting was detected.

(4) There is a marginal increase in the lustre of some rocks in the Oonah correlate as the boundary is approached. In the Concert Schist at the boundary the rocks are more lustrous and mineral segregation associated with the second cleavage becomes evident.

(5) Bedding in the Concert Schist near the boundary is of similar attitude to bedding in the Oonah Formation correlate. Although bedding was not confidently identified in the Concert Schist at the boundary the second foliation, to which bedding is commonly sub-para11e1, is of similar attitude to bedding in the Oonah formation correlate.

The absence of any indication of an erosional surface or of substantial faulting, combined with transition in lustre of the rocks and similar attitude of bedding indicates that there is no stratigraphic break between the Concert Schist and the Oonah Quartzite and Slate.
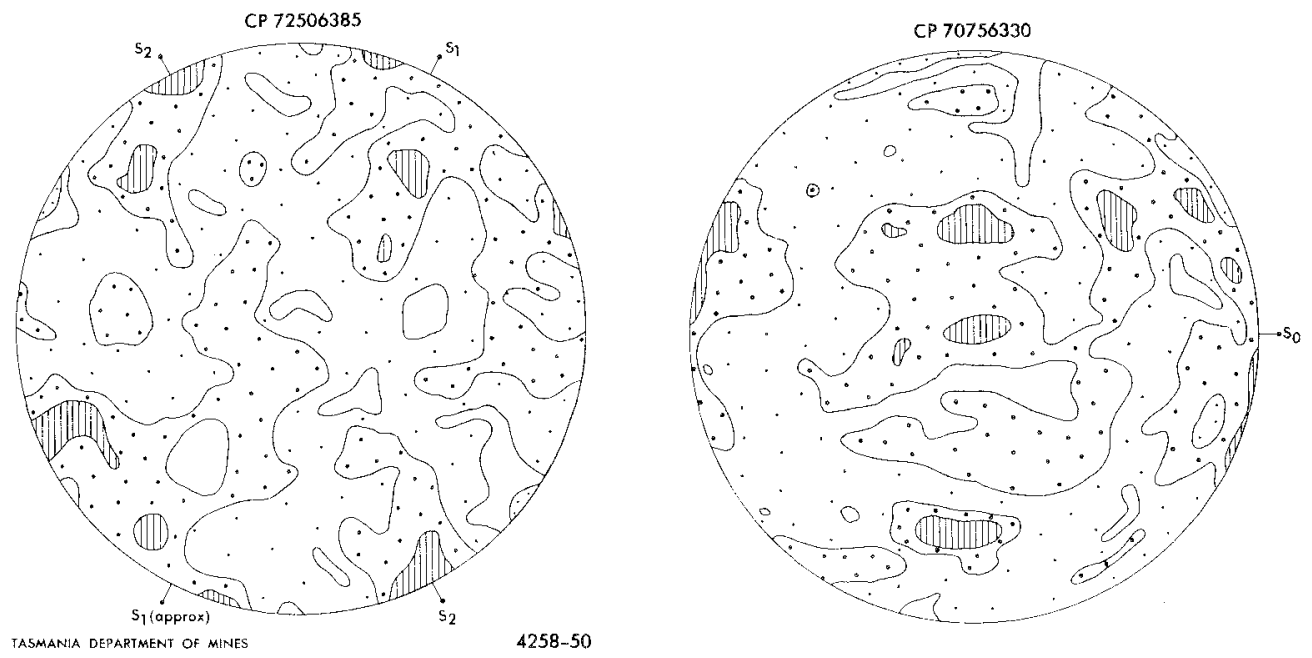

FIG. 2.- Quartz optic axes plots, 275 counts, contours 2, 1, 0\%. Sections perpendicular to the dominant lineation. Left-hand plot: Concert Schist, about $1 \mathrm{~km}$ from boundary on spur south of Concert Ck., Dundas. Right-hand plot: Oonah Quartzite and Slate correlate, west of Maestries Siding, Dundas. 
20

Boundary relationship of the Concert Schist and oonah Quartzite and Slate Correlate

\section{STRUCTURAL RELATIONSHIPS}

The third tectonic surface of the Concert Schist has continuity across the boundary with the second surface in the oonah Formation correlate and they are regarded as being the sanc. It has not been demonstrated which of the earlier surfaces in the concert schist is cquivalent to the first surface in the oonah Formation correl ate. A fow minor, open folds of short wave length and low anplitude occur in the Oonah Quartzite and site comelate. They postmate the oarier surface and predate the later. They have a cumbtion ineation parallel to their hinges. The cremulation might be equivalent to the second surfaco in the concert schist and thus indicate that the first cleavges in the Concor Sonist and the oonah correlate are equivalent.

\section{QUARTZ OPTIC AXES FABRICS}

In view of the textimal differences between the guartzite of the Concert Schist and the sandstone of the Donah Formation correlate j.t was anticipated that their quartz optic axes fabrics would be substantially different. This is not the case. Both fabrics are diffuse, have very low intensity maxima and show triclinic symmetry (fig. 2). There is no increase in ordering in the Concert Schist quartzite although a large proportion of the quartz grains are of metamorphic origin.

Quartz optic axes fabrics comparable with those presented here were found by Spry (1964) in psamite from the relatively unmetamorphosed Donaldson Group of the Pieman R. area (Rocky Cape region) and by Spry (1963) in psammite from the metamorphosed Fisher Group in the upper Mersey $\mathrm{R}$. area (Tyennan region). It is clear from Spry's results and those in this report that the two classes of precambrian strata in Tasmania cannot be categorized by the type of quartz optic axes fabric present in their psammites. A1though it is well established (e.g. Spry 1963) that rocks in the Tyennan Region can have quartz optic axes fabrics showing relatively strong preferred orientation, Spry's result for the Fisher Group psammite demonstrates that rocks having relatively weak preferred orientation are also present (c.f. Williams 1976, p. 6).

\section{ACKNOWLEDGEMENTS}

The author's attention was directed to the problem discussed in this paper by Dr. Emyr Williams, Supervising Geologist, Department of Mines who a150 provided helpful discussion during the course of the work. A.V. Brown, N. Farmer, and P.R. Williams aided by criticism of the manuscript.

\section{REEERENCES}

Blissett, A.H., 1962: One mile geological map series k/55-5-50 Zeehan. Explan. Rep. geol. Surv. Tasm.

Boulter, C.A. 1974: Tectonic deformation of soft sedimentary clastic dikes from the Precambrian rocks of Tasmania, Australia, with particular reference to their relations with cleavages. Buzl. Geot. Soc. Amer., 85: 1413-1420.

Spry, A.H., 1958: Some observations of the Jurassic dolerite of the Eureka cone Sheet, near Zeehan, Tasmania; in DOLERTTE - $A$ SYMPOSIUM, Univ. of Tasm. 93-129. - 1962: The precambrian Rocks. In Spry, A. and Banks, M.R. (Eds) : THE GEOLOGY OF TASMANIA. Jo geol. Soc. Amst., 9(2): 107-126. - 1963: Ripple marks and pseudo-wipple marks in deformed quartzite. Am.J. Sei., 261: 756-766.

- 1964: Precambrian rocks of Tasmania. part VI. The Zeehan-Corinna area. Pap. Proc. R. Soc. Tasm., 98: 23-48.

Tasmania Department of Mines, 1976: Geological map of Tasmania. Scale 1:500,000. Williams, E., 1976: Tasman fold belt system in Tasmania. Explanatory notes for the 1:500,000 structural map of PremCarboniferous rocks of Tasmania. Department of Mines, Tasmania. 